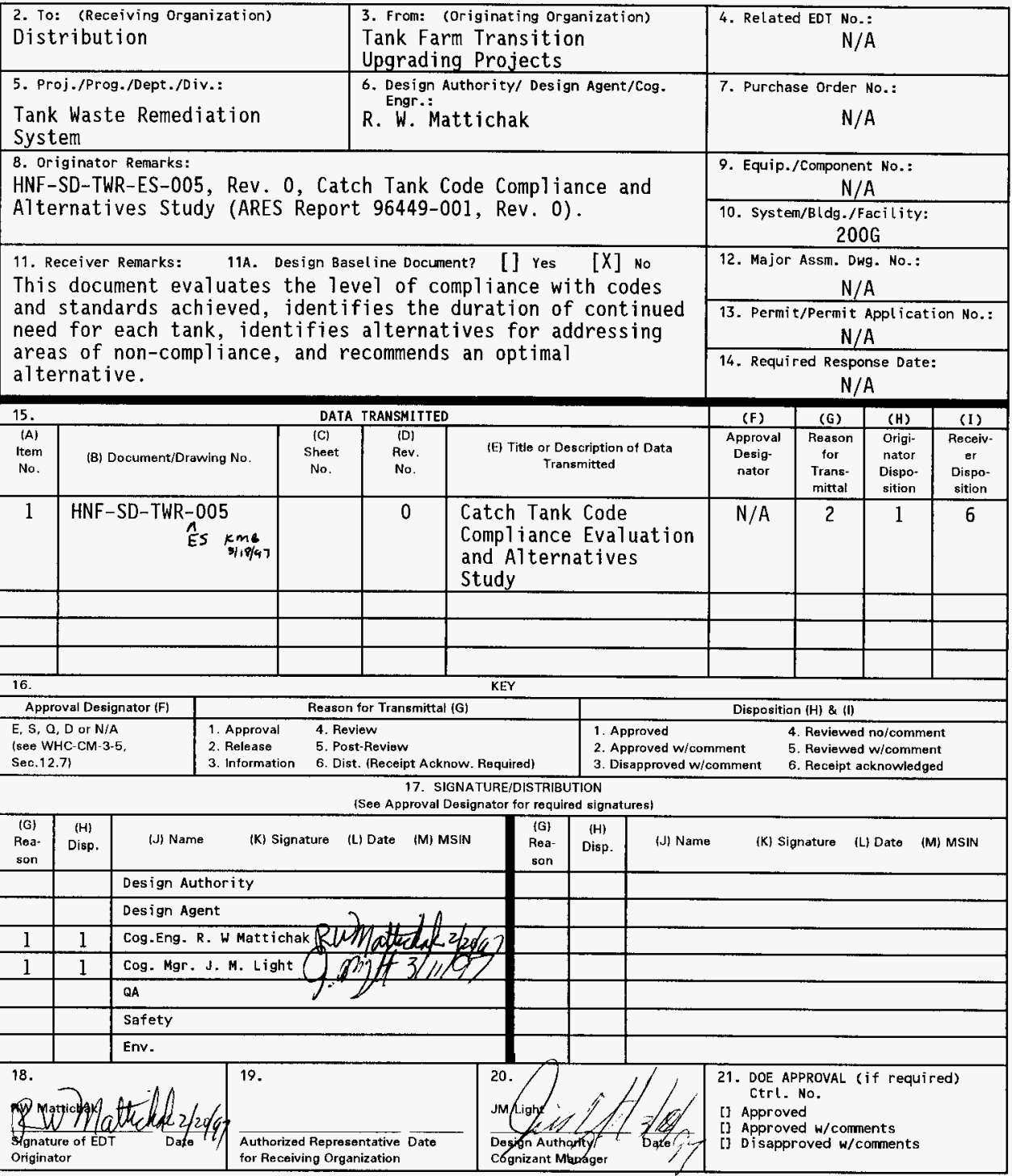




\section{Catch Tank Code Compliance Evaluation and Alternatives Study}

R. W. Mattichak

Numatec Hanford Corporation

P.0. Box 1300 R3-25

Richland, WA 99352

U.S. Department of Energy Contract DE-AC06-96RL13200

EDT/ECN: $607815 \quad$ UC: 2030

Org Code: $8 C 430$ Charge Code: N13Gl

B\&R Code: EW3130010 Total Pages: $3435 \mathrm{kmb} 3 / 18 / 97$

Key Words: Catch Tank, DCRT, MUST

Abstract: Evaluation for underground catch tanks against specific criteria by reviewing drawings, documents and conducting interviews with cognizant engineers. The results of this review are documented in a compliance matrix.

TRADEMARK DISCLAIMER. Reference herein to any specific comercial product, process, or service by trade name, trademark, manufacturer, or otherwise, does not necessarily constitute or imply its endorsement, recommendation, or favoring by the United States Government or any agency thereof or $i$ ts contractors or subcontractors.

Printed in the United States of America. To obtain copies of this document, contact: Document Control Services, P.O. Box 950, Mailstop H6-08, Richland WA 99352, Phone (509) 372-2420; Fax (509) 376-4989.
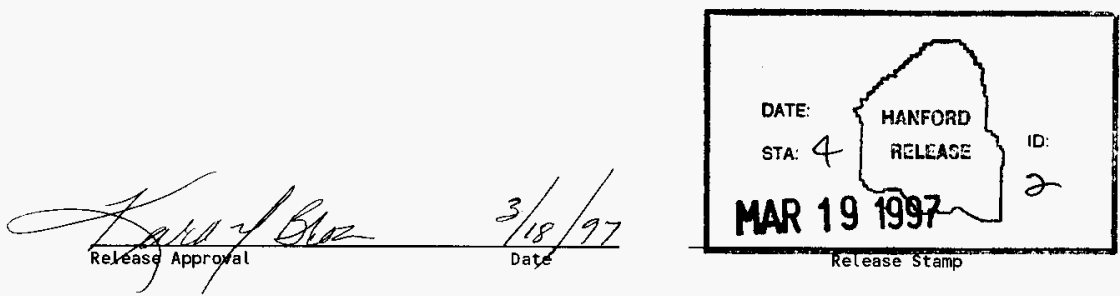

\section{Approved for Public Release}




\section{CATCH TANK CODE COMPLIANCE EVALUATION AND \\ ALTERNATIVES STUDY}

Prepared for

\section{FLUOR DANIEL NORTHWEST}

Purchase Order MRK-SBW-336070

Report No. 964449-001

Revision 0

January 1997

Prepared by: $\quad$ Steve D. Riesenweber Bruce D. Groth

Approved by:

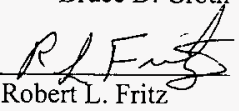

Date: $1-16-97$ 


\section{TABLE OF CONTENTS}

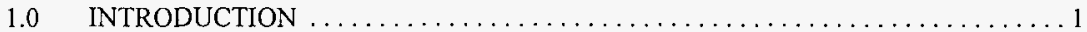

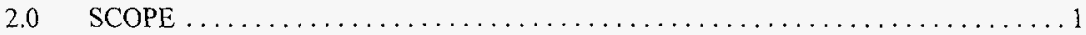

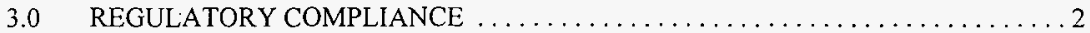

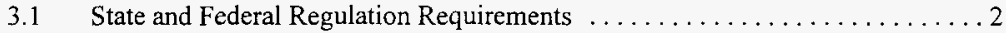

3.2 Compliance of Miscellaneous Underground Storage Tanks ............. 3

4.0 ALTERNATIVE EVALUATION $\ldots \ldots \ldots \ldots \ldots \ldots \ldots \ldots \ldots \ldots \ldots \ldots$

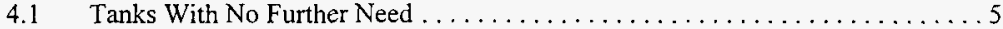

4.1.1 Alternative Identification . . . . . . . . . . . . . . . . . . 5

4.1.2 Common Alternative Evaluation Considerations $\ldots \ldots \ldots \ldots \ldots \ldots 5$

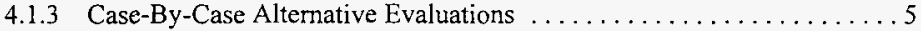

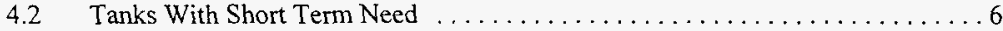

4.2.1 Alternative Identification . . . . . . . . . . . . . . . . . . 6

4.2.2 Common Alternative Evaluation Considerations $\ldots \ldots \ldots \ldots \ldots \ldots 7$

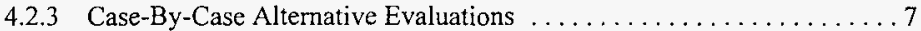

4.3 Tanks With Long-Term Need $\ldots \ldots \ldots \ldots \ldots \ldots \ldots \ldots \ldots \ldots$

4.3.1 Alternative Identification . . . . . . . . . . . . . . . . . . . 9

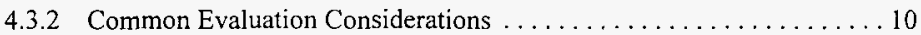

4.3 .3 Tanks with Long-Term Need . . . . . . . . . . . . . . . 10

5.0 PREFERRED ALTERNATIVE DEVELOPMENT $\ldots \ldots \ldots \ldots \ldots \ldots \ldots \ldots \ldots$

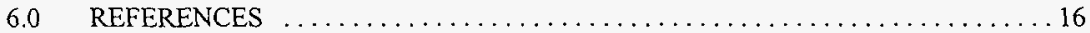

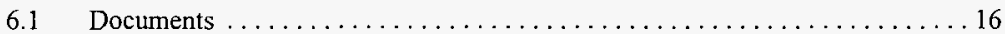

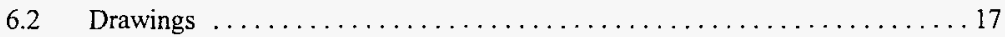

\section{APPENDICES}

Appendix A

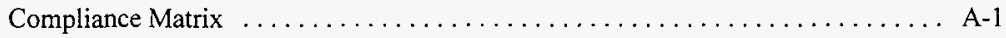

Appendix B

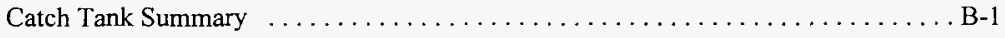




\section{ACRONYMS}

DCRTs

Ecology

IMUST

MUST

PFP

ROM

SST

WAC
Double Shell Receiver Tanks

Washington State Department of Ecology

Inactive Miscellaneous Underground Storage Tank

Miscellaneous Underground Storage Tank

Plutonium Finishing Plant

Rough Order of Magnitude

Single-Shell Tank

Washington Administrative Code 


\subsection{INTRODUCTION}

Several small tanks associated with the Hanford Site Tank Farms, generally called "catch tanks", were identified as being in need of an assessment to determine whether they are in compliance with specific State and Federal regulations, and to identify what alternatives are available to manage these tanks in a manner which is agreeable to the Washington State Department of Ecology (Ecology) and the U.S. Department of Energy. These tanks have capacities ranging between a few hundred gallons and fifty-thousand gallons. They are used primarily to provide secondary containment for transfer lines, seal loops, and valve or diversion boxes, although some of the tanks reviewed in this document are used to provide primary containment.

In several documents reviewed, the term "catch tank" was only used to describe tanks that provided a secondary containment for waste and rainwater leaked into valve and diversion box pits. However, this definition was found to be too narrow for the purpose of this evaluation since some of the tanks are Double Shell Receiver Tanks (DCRTs). The term Miscellaneous Underground Storage Tanks (MUST) has been used more recently to refer to the entire group of these small primary and secondary containment tanks.

For each MUST tank, this document evaluates the level of compliance with codes and standards achieved, identifies the duration of continued need for each tank, identifies alternatives for addressing areas of non-compliance, and recommends an optimal alternative.

\subsection{SCOPE}

The scope of this evaluation was limited to assessing the MUSTs and Special Surveillance Facilities listed in the Waste Tank Summary Report (Hanlon 1996) for compliance with the Environmental Protection Agency and Ecology regulations relating to "Tank Systems". These tanks are located in the 200 East and 200 West Areas, with the exception of Tank 241-ER-151 which is located approximately 1,500 feet south of the fire station between the 200 East and 200 West Areas. The list of tanks evaluated is as follows.

200 East Area

241-A-302A

241-ER-311

$241-\mathrm{AX}-152$
200 West Area

241-TX-302C

$241-\mathrm{U}-301 \mathrm{~B}$

24I-UX-302A 
200 East Area

241-AZ-151

241-AZ-154

241-A-350

204-AR TK 1

241-A-417

244-A DCRT

\section{4-BX DCRT}

244-CR TK-003

\section{West Area}

241-S-304

244-S DCRT

244-TX DCRT

241-ER-151

\subsection{REGULATORY COMPLIANCE}

The codes/regulations that the tanks are evaluated against are Washington Administrative Code (WAC) WAC-173-303-640 Tank Systems, and U.S. Code of Federal Regulations 40 CFR 265, Subpart $J$ - Tank Systems. These regulations are limited to the design, operation, and ongoing assessment of primary and secondary tank systems that store hazardous wastes. On certain tanks, a few deficiencies were identified with respect to other codes; these are not within the scope of this evaluation. These deficiencies are noted in the following sections, but are not factored into the recommendations for tanks. All of the tanks evaluated were constructed before current State and Federal Dangerous Waste Regulations were put in effect. Therefore, none of the tanks are currently in complete compliance with all areas of the code requirements.

\subsection{State and Federal Regulation Requirements}

WAC-173-303-640, Tank Systems, has the same requirements as the applicable Federal regulation which is 40 CFR 265 Subpart J - Tank Systems. In this evaluation, the WAC regulation was used as the reference source. A summary of the main requirements of this regulation follows. Applicable WAC-173-303-640 sections are in brackets.

- Tanks that provide primary containment of waste must be provided with secondary containment. For existing systems of known and documented age this must be provided within two years after January 12,1989, or when the tank system reaches 15 years of age, whichever comes later [(4)(a)(iii)]. 
- Tanks (primary or secondary containment) must have adequate corrosion protection $[(3)(\mathrm{g})]$.

- Tanks (primary or secondary containment) must have an adequate foundation [(3)(a), (4)(c)(ii)].

- Tanks must be provided with a leak-detection system that is capable of detecting the failure of either the primary or secondary containment structure within 24 hours $[(4)(\mathrm{c})(\mathrm{ii})]$.

- Tank operations must use appropriate controls and practices to prevent spills and overflows [(5)(b)].

- An integrity assessment shall be performed for existing tank systems by January 12,1988 $[(2)(a)]$. A schedule for conducting integrity assessments over the life of the tank must also be developed $[(2)(e)]$.

- Secondary containment must be constructed of a material, or contain a liner that is impermeable and compatible with the stored waste $[(4)(\mathrm{c})(\mathrm{I})]$.

- Secondary containment must be sloped or otherwise designed to drain and remove fluids [(4)(c)(iv)].

- Spilled or leaked waste and accumulated precipitation must be removed from the secondary containment system within 24 hours, or in as timely manner as possible $[(4)(\mathrm{c})(\mathrm{iv})]$.

\subsection{Compliance of Miscellaneous Underground Storage Tanks}

The identified tanks were evaluated against the criteria summarized above by reviewing drawings, documents, and conducting interviews with the cognizant engineers. The results of this review are documented in a compliance matrix in Appendix A. None of the tanks evaluated were compliant in all areas. For example, all the tanks that are to remain in operation require an integrity assessment, some of the secondary containments are not sloped or otherwise designed for pumping, and some of the tanks do not have adequate corrosion control.

Another requirement which merits special consideration is the requirement to pump liquid from secondary containment "within 24 hours or in as timely a manner as possible". Tank Farms transfer configurations and operating constraints do not make it practical to transfer liquids from 
secondary containment within 24 hours from the time that liquid enters these tanks. DCRTs do not normally have a liquid level in their secondary containment; liquid accumulated in this area would most likely be the result of a primary containment leak. All DCRTs that are provided with adequate secondary containment, are set up to detect and contain this type of condition. The remaining MUSTs are catch tanks that serve as secondary containment. They currently routinely receive "low consequence" liquid input through such sources as rainwater intrusion into diversion boxes, loop seals, and other similar sources. These tanks are administratively controlled so that they are pumped by the time the tank level reaches 80 percent of capacity or prior to another waste transfer which has the potential to overfill the catch tank in the event of a primary leak (WHC 1995). This approach is consistent with the allowances in the WAC code which allows pumping ".... in as timely a manner as possible". Discussions are currently ongoing to assure that these operating practices are acceptable to Ecology.

Alternatives for managing the deficiencies identified for each tank are contained in section 4.0 . The reader is referred to Olander (1990) and Palit (1996) as well as the drawings listed in section 7.2 for additional details and sketches of the tanks if desired.

\subsection{ALTERNATIVE EVALUATION}

The following process was used to assess the Tank Farms MUSTs degree of compliance with respect to the applicable WAC and develop recommendations for managing or correcting the deficiencies identified. After completion of the compliance evaluation (Appendix A), tanks were grouped into three bins according to their planned future need. This is due to the fact that tanks with a similar remaining need duration often warrant a comparable investment of resources toward compliance. The bins include: 1) Tanks with no further need, 2) Tanks with short-term need (less than five years), and 3) Tanks with long-term need (greater than five years). Once the tanks were binned with respect to their time need duration, alternatives common to the bin in question were identified and discussed as a group. Finally, the tanks were evaluated on a caseby-case basis and a recommendation made for each tank. Within this effort, specific ways of applying alternatives were identified and weighed for each tank based upon the tank's actual condition, need, ability to meet requirements, and cost to apply the alternative.

The following sections contain the results of this evaluation process. Appendix B contains a table which summarizes tank future uses, deficiencies, alternatives and recommendations. 


\subsection{Tanks With No Further Need}

Tanks that fall into this need category are:

$$
\begin{array}{ll} 
& 241-\mathrm{A}-302-\mathrm{A} \\
\mathbf{2} & 241-\mathrm{AZ}-154 \\
& 241-\mathrm{TX}-302-\mathrm{C}
\end{array}
$$

\subsubsection{Alternative Identification}

- Remove the tank from service and begin closure procedures to transfer to the Inactive Miscellaneous Underground Storage Tanks (IMUSTs). This involves the following steps:

- Isolate the tank by capping all incoming lines and pits covers which are a source of liquid.

- $\quad$ Pump remaining free liquids.

- Cover catch tank pits to seal from rainwater infiltration.

- Continue operation with the tank as is. This will require negotiation with state regulators at Ecology.

\subsubsection{Common Alternative Evaluation Considerations}

The most reasonable alternative that can be recommended to meet regulatory goals, reduce risk, and minimize life-cycle costs is to isolate, pump out to minimal heel, and place on the IMUST list for final closure. This is based on the current negotiations with Ecology that say, for catch tanks, once stabilized and placed on the IMUST list monitoring will no longer be required. This means that the costs and manpower associated with current pumping and monitoring operations would be available for other site purposes.

A Rough Order of Magnitude (ROM) cost for the surveillance and operation of a catch tank acting as secondary containment is $\$ 15,000$ per year. This estimate assumes that no jumper changes are required to make transfers; these are estimated at $\$ 40,000$ to $\$ 50,000$.

\subsubsection{Case-By-Case Alternative Evaluations}

The following tanks were determined to not have any further mission and are recommended to be isolated, pumped to a minimal heel, and placed on the IMUST list for final closure as soon as is practical. 
- $\quad$ Tank 241-A-302-A

This tank collects drainage from the 241-A-151 diversion box which was used for transfers from PUREX. The tank provides secondary containment and is a single wall direct buried tank. Transfers through this diversion box are no longer required and it is recommended that the tank be closed.

- $\quad$ Tank 241-AZ-154

This tank collects condensate from the 241-AY and 241-AZ steam heating coils. The coils have not been in use for years, there are no plans to use them, and some or possibly all of the lines have already been blanked off (Reberger and Tardiff 1996). The tank should be isolated and made ready for closure as soon as possible.

- $\quad$ Tank 241-TX-302-C

This tank collects drainage from the 241-TX-154 diversion box which supports waste transfers from T-Plant. This diversion box is no longer used due to noncompliant transfer lines, and all transfers from T-Plant are now being performed by rail car (Erickson 1996). The tank should be isolated and made ready for closure as soon as possible.

4.2 Tanks With Short Term Need-- less than five year need duration. Tanks that fall into this need category are:

- 241-ER-311

- 241-AX-152

- 241-A-417

- 244-BX DCRT

- 244-CR TK-003

- 241-EW-151.

4.2.1 Alternative Identification-- less than five year need duration

- Conduct an integrity assessment.

- Negotiate with state regulators at Ecology to continue operation of the tank, without upgrades until no further mission need exists. Then, remove the tank from service and begin closure procedures to transfer to the IMUSTs. 
- $\quad$ Perform a partial upgrade of the tank system to bring certain areas into compliance. Specifically, all areas accept actual replacement of the tank will be considered. This may require negotiation with state regulators at Ecology.

- Continue operation with the tank as is. This will also require negotiation with state regulators at Ecology.

- Perform a total upgrade of the tank system to bring all areas into compliance. Specifically, replace the entire tank and associated systems.

\subsubsection{Common Alternative Evaluation Considerations--less than five years need duration.}

Alternatives for tanks with a short-term need were evaluated on a qualitative basis. Replacement of the tank system was discarded as a viable alternative since the time involved in completing a General Plant Project (estimated at 1.5 years) and the cost of the system (ROM estimate $\$ 1.2$ million) is not merited due to the limited amount of use the new tank would realize before it was placed on the IMUST list. It would be much more cost effective to closely monitor and operate a system to reduce risk, perform limited upgrades where appropriate, and continue to operate it until mission completion. Once the mission is complete, it can then be isolated, pumped out to minimal heel, and placed on the IMUST list for final closure.

Limited upgrades that do not require completely replacing the tank system, were evaluated on a case-by-case basis depending on the risk associated with correcting the noncompliance.

For tanks within this bin, a need duration greater than three years has been established as a threshold where an integrity assessment is recommended. Three years was established to coincide with the Hanford Federal Facility Agreement and Consent Order [Tri-Party Agreement)] Milestone, M-32-00, which requires integrity assessments by September 30, 1999.

\subsubsection{Case-By-Case Alternative Evaluations}

- Tank 241-ER-311

This tank collects drainage from the 241-ER-151 and 241-ER-152 diversion boxes. These diversion boxes support the existing cross-site transfer lines, and B- 
Plant transfer lines. The new Project W-058 Replacement Cross-Site Transfer Line is scheduled for completion in August 1998, and B-Plant clean out is also to be completed in 1998. Once these are completed, this tank is no longer required and it should be isolated and made ready for closure. Because of the short duration of the remaining need for this tank, no further actions are recommended.

- $\quad$ Tank 241-AX-152

This tank collects drainage from A- and B- diverter cell floor drains, AY-501 valve pit floor drains, 241-AX-155 diversion box floor drain, PUREX transfer line V-714 encasement drain, 110 seal loop drain, K1-5-1 deentrainers, and 702-A seal pot overflow line. Once the Project W-030 Aging Waste Ventilation System Upgrade is complete, an alternate route can be utilized for the encasement drain and the tank closed out (Reberger and Tardiff 1996). Project W-030 is scheduled for completion in 1997. Because of the short duration of the remaining need for this tank, no further actions are recommended.

- Tank 241-A-417

This tank collects condensate from A-702 and three surface condensers (E-413, E414 , and E-415) along with the condenser seal loop drains, and the 241-AX-501 valve pit drain. Once the Project W-030 Aging Waste Ventilation System Upgrade is complete, all the condensate lines can be isolated, and the valve pit drain is no longer required after closure of 241-AX-152. With completion of Project W-030 in 1997, the tank should be isolated and made ready for closure. Because of the short duration of the remaining need for this tank, no further actions are recommended.

\section{- $\quad \underline{\text { Tank 244-BX DCRT }}$}

This tank is used for interim storage of saltwell waste from the 241-B, 241-BX, and 241-BY single-shell tanks (SSTs) and is, therefore, required to provide primary and secondary containment of the waste. Once the saltwell pumping of these tanks is completed (prior to FY 2000), the DCRT can be removed from service, pumped to a minimal heel, and placed on the IMUST list for final closure. In the interim, the tank is only out of compliance in two areas. It is recommended that an integrity assessment of the tank be performed, and that Ecology be made aware that it is not possible to pump liquids out of the secondary containment sump within 24 hours should a need arise to do that. 


\section{- $\quad$ Tank 244-CR TK-003}

This tank is used for interim storage of saltwell waste from the 241-C farms. The only tank remaining to be stabilized within this farm is $103-\mathrm{C}$. When this action is completed, the tank will no longer be required for future use and should be isolated and placed in the IMUST list. In the interim, it is recommended that an integrity assessment be performed. All SST stabilization is scheduled to be completed by September 2000 .

\section{- $\quad$ Tank 241-EW-151}

This tank is located at the existing cross-site transfer line vent station, and is used to collect any waste that might enter the vent lines during venting. The Project W-058 Replacement Cross-Site Transfer Line is scheduled for completion in August, 1998. When this item is complete, the tank should be isolated and made ready for closure. Because of the short duration of the remaining need for this tank, no further actions are recommended.

4.3 Tanks With Long-Term Need--greater than five years. Tanks that fall into this need category are:

$\begin{array}{ll} & 241-A Z-151 \\ & 241-A-350 \\ & 204-A R \text { TK-1 } \\ & 244-A \text { DCRT } \\ & 241-U-301 B \\ & 241-S-304 \\ & 244-S \text { DCRT } \\ & 244-T X \text { DCRT } \\ & 241-\text { UX-302A. }\end{array}$

4.3.1 Alternative Identification--greater than five years.

- Conduct an integrity assessment.

- Determine and implement another means of meeting the functions the tank provides and begin closure procedures to transfer to the IMUSTs.

- Perform a partial upgrade of the tank system to bring certain areas into compliance. Specifically, all areas except actual replacement of the tank will be 
considered. This may require negotiation with state regulators at Ecology.

- Perform a total upgrade of the tank system to bring all areas into compliance. Specifically, replace the entire tank and associated systems.

- Negotiate with state regulators at Ecology to continue operation with the tank, without upgrades until no further mission need exists. Then, remove the tank from service and begin closure procedures to transfer to the IMUSTs.

\subsubsection{Common Evaluation Considerations--greater than five years.}

For tanks with long-term needs, a more rigorous risk-based approach for determining the preferred alternative is necessary, particularly for those tanks that do not have required secondary containment. This is because the potential risk to the environment is greater, and the capital costs of upgrading the tank system to be in compliance could also be greater.

To evaluate the alternatives, a ROM cost estimate to implement the alternative is weighed against the risks involved of not implementing the alternative. Factors to consider for risk are the length of time the tank is to remain in service, the current age of the tank, materials of construction, the hazards associated with the waste entering the tank, the quantity of material maintained in the tank along with the quantity of throughput, and the cost estimate for completing the upgrade.

\subsubsection{Tanks with Long-Term Need}

\section{- Tank 241-AZ-151}

This tank is currently used to collect condensate from the 241-AZ-101 and 102 vent header seal loops, drainage from the 241-AZ leak detection pits, drainage from the 241-AZ-801 A instrumentation building floor drain, and drainage from the 241-AZ-152 sluicing transfer box. This catch tank will continue to be needed for the long term to provide a secondary collection point for all of these locations plus condensate drains from the new Project W-030 Aging Waste Ventilation System Upgrade when it is placed on line in 1997 . The tank provides primary containment for the Project W-030 condensate; however, no secondary containment is provided in the catch tank arrangement. 
The 24-year-old tank is a concrete vault lined with 10 gage carbon steel. Being encased in concrete, the carbon steel liner does not require cathodic protection so no deterioration is expected due to galvanic action. The tank contents are not routinely treated to inhibit general internal corrosion; however, a recent report assessing the need to add corrosion inhibitors concluded that no chemical adjustment was recommended due to the fact that the tank is pumped out at regular intervals (Palit 1996).

Deficiencies for this tank include:

1. The lack of secondary containment in a tank which is expected to be used for primary containment for a long duration is considered to be a serious high risk deficiency.

2. No integrity assessment has been completed for this tank system.

It is not feasibie from the physical configuration of this tank to upgrade it to have adequate secondary containment. Thus, it is recommended that the system be upgraded by completely replacing the catch tank with a tank that provides proper secondary containment. The ROM cost of such a replacement is $\$ 1.2$ million. Alternately, it may be possible to route the Aging Waste Ventilation System condensate to a compliant tank. This alternative may not be possible due to hydraulic considerations; if feasible, it would require rerouting of drain lines.

\section{- Tank 241-A-350 Lift Station}

This tank receives drainage from 241-A-A and B valve pits, and 241-A clean out boxes. It also acts as a lift station for transferring waste from the 207-A retention basin to Tank 241-AW-102. This transfer function is needed when the 242-A Evaporator condensate, staged in the retention basin, is sampled and found to be out of specifications for the Treated Effluent Disposal Facility. This use of the catch tank is primary containment.

This 18-year-old tank is constructed of stainless steel; it is installed in a carbon steel caisson which has a concrete floor and sump. The caisson enclosure acts as the secondary containment. The Cognizant Engineer reports that the tank system does not conform to the original design criteria. It was intended to have automatic pumping capabilities which were never installed. 
The following code deficiencies have been identified:

1. The design of the secondary containment may be inadequate to assure that all waste leaked from the primary tank will be contained. This is due to uncertainty on the construction of the joint where the caisson and the concrete floor of the sump meet. Available drawings do not provide enough detail to confirm whether this joint is adequate or not.

2. The caisson providing secondary containment does not have cathodic protection.

3. No integrity assessment has been performed.

The code deficiencies associated with this tank are considered to constitute only a low risk condition since no liquid level is normally maintained in the secondary containment and a leak to the secondary would be readily detected. Further, the transfer of waste from the retention basin is the only potential waste that would constitute a primary containment function for this tank. All other sources of liquid are due to rainwater intrusion or a leak in a primary line in a valve pit (secondary functions). The retention basin transfer is a contingency which is not likely to ever be required; it would only be necessitated by failure of the steam tube bundle in the evaporator. Thus, it is recommended that an integrity assessment be performed which provides assurance of the soundness of both the primary and secondary. Depending upon the results of this assessment, a partial upgrade can be performed to clean the sump and apply a sealant if needed.

- $\quad$ Tank 204-AR TK-1

This tank is used to collect potential leaks from primary systems during the pumping of rail cars or trucks. The catch tank collects leaks through the floor drain system in the 204-AR Waste Unloading Facility. As such, it is providing secondary containment.

The only code deficiencies identified are:

1. No integrity assessment has been performed.

2. The catch tank is not operated to remove liquid within 24 hours.

The deficiencies constitute a low risk since the tank secondary is backed up by a conductivity leak detection probe located in the concrete vault (tertiary confinement) that contains the tank. It is recommended that an integrity assessment be performed, and the tank be included in negotiations with Ecology as to what is considered a practical time frame for removing waste from the tank. 
- $\quad$ Tank 244-A DCRT

This tank is used to collect drainage from 241-ER-153 diversion box, and the 241A-A and 241-A-B valve pits--secondary containment functions. It also provides primary containment for salt well pumping of 241-B, 241-BX, 241-BY, and 241C SST waste as well as waste transferred from B-Plant--primary containment functions with short-term needs. The new Project W-058 Replacement Cross-Site Transfer line terminates in the 244-A DCRT; this constitutes a long term primary containment function. However, Project W-314 currently plans to bypass this DCRT for the cross-site transfer uses by extending the cross-site line to AN Farm sometime between the year 2000 and 2005 .

The tank is out of compliance with WAC-173-303-640 in two areas:

1. No integrity assessment has been performed

2. The catch tank is not operated to remove liquid within 24 hours.

These deficiencies constitute a low risk since the secondary containment is normally dry and the only likely way waste will enter the secondary containment is by the leakage from the primary tank. This leakage will be well contained and detected quickly. It is recommended that an integrity assessment be performed, and the secondary tank be included in negotiations with Ecology as to what is considered a practicable time frame for removing waste.

- $\quad$ Tank 241-U-301B

This tank is used to collect drainage from diversion $241-\mathrm{U}-151,241-\mathrm{U}-152$, and 241-U-153 diversion boxes. These are secondary containment functions. The diversion boxes support transfers from the 244-TX DCRT which has a need through at least 2006.

Code deficiencies for this catch tank are as follows:

1. No integrity assessment has been performed

2. The catch tank is not operated to remove liquid within 24 hours.

3. The tank is constructed of unlined concrete.

4. The tank is not equipped with a sloped floor or sump to facilitate complete pumping. 
These deficiencies constitute a moderate risk. The tank is old (approximately 52 years), and being unlined, porous. This means that if a leak were to occur in a primary system within a diversion box, this catch tank would not assure prevention of contamination spread to the ground. The tank is currently operated with a liquid level in it generated from rain water intrusion. The tank level is administratively controlled to the requirements of OSD 15 . It is not feasible to line the existing tank for cost and ALARA reasons. Thus, it recommended that this tank be replaced.

- $\quad$ Tank 241-S-304

This tank receives drainage from the 241-S-151 diversion box--a secondary containment function. This diversion box is likely to remain in operation for more than five years in support of Plutonium Finishing Plant (PFP) transfers. The primary tank is located in a carbon steel lined concrete vault and the primary tank is constructed of carbon steel.

Two code deficiencies have been identified with this tank:

1. No integrity assessment has been performed

2. The catch tank is not operated to remove liquid within 24 hours.

These deficiencies constitute a low risk since the tank is only five years old. It is recommended that an integrity assessment be performed, and negotiations continue with Ecology to agree upon waste level management as described in OSD 15.

- $\quad$ Tank 244-S DCRT

This DCRT supports 241-S and 241-SX saitwell pumping and other 200 West Area transfers. There is a long-term need under the current configuration for support of transfers from the 222-S Laboratory via 219-S. The primary tank is located in a carbon steel lined concrete vault and the primary tank is constructed of carbon steel.

The tank is out of compliance with WAC-173-303-640 in two areas:

1. No integrity assessment has been performed

2. The catch tank is not operated to remove liquid within 24 hours. 
These deficiencies are constitute a low risk since the secondary containment is normally dry and the only likely way waste will enter the secondary containment is by the leakage from the primary tank. This leakage will be well contained and detected quickly. It is recommended that an integrity assessment be performed, and the secondary tank be included in negotiations with Ecology as to what is considered a practical time frame for removing waste.

- $\quad$ Tank 244-TX DCRT

This DCRT supports 241-T, 241-TX, and 241-TY saltwell pumping. There is also a long-term need to support transfers from PFP. The primary tank is located in a carbon steel lined concrete vault and the primary tank is constructed of carbon steel.

The tank is out of compliance with WAC-173-303-640 in two areas:

1. No integrity assessment has been performed

2. The catch tank is not operated to remove liquid within 24 hours.

These deficiencies constitute a low risk since the secondary containment is normally dry and the only likely way waste will enter the secondary containment is by the leakage from the primary tank. This leakage will be well contained and detected quickly. It is recommended that an integrity assessment be performed, and the secondary tank be included in negotiations with Ecology as to what is considered a practical time frame for removing waste.

- $\quad$ Tank 241-UX-302A

This tank is used as secondary containment to diversion box 241-UX-154 which supports the current cross-site transfer system. This function will be eliminated with the startup of the Project W-058 cross-site transfer system in February 1998. The catch tank is also tied to the $291-\mathrm{U}$ stack and encasement drains; this facility has been turned over for decommissioning and demolition and it is unlikely that there is any need for the drain lines. However, since it was not possible to verify at this time that the latter needs are not long term, this tank has been binned with the long-term needs. 
Five deficiencies or potential deficiencies have been identified:

1. No integrity assessment has been performed

2. The tank is direct buried with a cold tar coating on the exterior; if flaws exist in this coating, galvanic corrosion may present a problem

3. The tank is direct buried; based on available information, it was not possible to verify that the soil adjacent to the tank provides adequate foundation.

4. The tank is not equipped with a sloped floor or sump to facilitate complete pumping.

5. The catch tank is not operated to remove liquid within 24 hours.

These deficiencies constitute a low risk since existing cross-site transfer system is only expected to operate one more time before the startup of the Project W-058 system and since the potential for significant quantities of U-Plant drainage is low. Further, the tank is monitored for leakage by level instrumentation and the level is controlled administratively according to OSD 15. It is recommended that the tank continue to be operated as-is until the completion of Project W-058 after which the U-Plant input sources should be isolated and the tank be placed on the IMUST list.

\subsection{PREFERRED ALTERNATIVE DEVELOPMENT}

To be completed at a later date.

\subsection{REFERENCES}

\subsection{Documents}

40 CFR 265, Subpart J - Tank Systems, U.S. Code of Federal Regulations, 1995 edition.

WAC-173-303-640, Tank Systems, Dangerous Waste Regulations of the Washington Administrative Code, 1995 edition.

Hanlon, B.M., 1996, Waste Tank Summary Report for Month Ending April 30, 1996, WHC-EP0182-97, Westinghouse Hanford Company, Richland, Washington. 
Olander, A.R., 1990, Double-Shell Tank Ancillary Equipment Secondary Containment Evaluation, WHC-SD-WM-EV-040, rev. 1, Westinghouse Hanford Company, Richland, Washington.

Palit, A.N., 1996, Letter Report - Catch Tanks Inhibitor Addition 200 East and 200 West Areas, WHC-SD-WM-ER-573, rev. 0, prepared by ICF Kaiser Hanford Company for Westinghouse Hanford Company, Richland, Washington.

Reberger, D.W., and G.R. Tardiff, 1996, Record of Conversation - 200 East Catch Tank - 274$A W, 96 \mathrm{RL} 1131$, ARES Corporation, Richland, Washington.

Scott, K.V., 1996, Record of Conversation - Catch Tank Integrity Assessments, 96RL1110, ARES Corporation, Richland, Washington.

WHC 1995, Unclassified Operating Specifications for Miscellaneous Facilities, OSD-T-15100015, Rev. B-8, Westinghouse Hanford Company, Richland, Washington.

\subsection{Drawings}

$\begin{array}{llll}\text { H-2-2537 } & \text { H-2-38203 } & \text { H-2-38204 } & \text { H-2-40180 } \\ \text { H-2-43148 } & \text { H-2-44612 } & \text { H-2-44681 } & \text { H-2-44683 } \\ \text { H-2-53096 } & \text { H-2-56800 } & \text { H-2-57302 } & \text { H-2-68315 } \\ \text { H-2-68316 } & \text { H-2-68367 } & \text { H-2-69153 } & \text { H-2-70318 } \\ \text { H-2-70538 } & \text { H-2-70539 } & \text { H-2-70705 } & \text { H-2-71049 } \\ \text { H-2-71052 } & \text { H-2-71643 } & \text { H-2-71644 } & \text { H-2-71653 } \\ \text { H-2-71660 } & \text { H-2-71665 } & \text { H-2-71670 } & \text { H-2-73786 } \\ \text { H-2-73789 } & \text { H-2-73908 } & \text { H-2-73919 } & \text { H-2-73933 } \\ \text { H-2-76560 } & \text { H-2-85036 } & \text { H-2-85037 } & \end{array}$




\section{Appendix A}

Compliance Matrix 
Active Miscellaneous Underground Storage Tanks Environmental Compliance Matrix

WAC-173-303-640

\begin{tabular}{|c|c|c|c|c|c|c|c|c|c|c|c|}
\hline \multirow{2}{*}{ Tank } & \multirow{2}{*}{$\begin{array}{c}\text { Age } \\
\text { (years) }\end{array}$} & \multirow{2}{*}{$\begin{array}{l}\text { Containment } \\
\text { Classification/Waste } \\
\text { Sources }\end{array}$} & \multicolumn{5}{|c|}{ Primary and Secondary Containment } & \multirow{2}{*}{$\begin{array}{c}\text { Primary } \\
\text { Containment } \\
\text { Provided with } \\
\text { Proper } \\
\text { Secondary } \\
\text { Containment? }\end{array}$} & \multicolumn{3}{|c|}{ Secondary Containment } \\
\hline & & & $\begin{array}{l}\text { Corrosion } \\
\text { Protection? }\end{array}$ & $\begin{array}{l}\text { Foundation } \\
\text { Adequate? }\end{array}$ & $\begin{array}{l}\text { Leaks } \\
\text { Detected } \\
\text { within } 24 \\
\text { hours? }\end{array}$ & $\begin{array}{l}\text { Overflow } \\
\text { Protection }\end{array}$ & $\begin{array}{c}\text { Integrity } \\
\text { Assessment } \\
\text { Performed? }\end{array}$ & & $\begin{array}{c}\text { Lining } \\
\text { Compatible } \\
\text { with Waste? }\end{array}$ & $\begin{array}{c}\text { Sloped/ } \\
\text { Designed to } \\
\text { be pumped? }\end{array}$ & $\begin{array}{c}\text { Leaked Waste } \\
\text { Removed } \\
\text { within } 24 \\
\text { hours? }\end{array}$ \\
\hline \multicolumn{12}{|c|}{200 EAST AREA TANKS } \\
\hline 241-A-302-A & 42 & $\begin{array}{l}\text { Secondary containment, } \\
\text { collects drainage from } \\
241-\mathrm{A}-151 \text { diversion } \\
\text { box }\end{array}$ & $\begin{array}{l}\text { No cathodic } \\
\text { protection, direct } \\
\text { buried carbon steel }\end{array}$ & $\begin{array}{l}\text { Indeterminate, } \\
\text { rests on sand bed }\end{array}$ & $\begin{array}{l}\text { Yes, relies on } \\
\text { weight factor } \\
\text { level gauge }\end{array}$ & $\begin{array}{l}\text { Yes, pumped when } \\
50 \% \text { full, } \\
\text { administratively } \\
\text { controlled to } 80 \% \\
\text { capacity (OSD-15) }\end{array}$ & No & N/A & Yes & $\begin{array}{l}\text { No, level } \\
\text { bottom }\end{array}$ & $\begin{array}{l}\text { No, level } \\
\text { administratively } \\
\text { controlled to } \\
80 \% \text { of } \\
\text { capacity }\end{array}$ \\
\hline 241-ER-311 & 42 & $\begin{array}{l}\text { Secondary containment, } \\
\text { as the drains that flow to } \\
\text { it are all diversion box } \\
\text { floor drains ( } 241 \text {-ER- } \\
151 \& 241 \text {-ER-152) }\end{array}$ & $\begin{array}{l}\text { No cathodic } \\
\text { protection, direct } \\
\text { buried stainless } \\
\text { steel }\end{array}$ & $\begin{array}{l}\text { Indeterminate, } \\
\text { rests on sand bed }\end{array}$ & $\begin{array}{l}\text { Yes, relies on } \\
\text { FIC level } \\
\text { gauge }\end{array}$ & $\begin{array}{l}\text { Yes, pumped when } \\
50 \% \text { full, } \\
\text { administratively } \\
\text { controlled to } 80 \% \\
\text { capacity (OSD-15) }\end{array}$ & No & N/A & Yes & $\begin{array}{l}\text { No, level } \\
\text { bottom }\end{array}$ & $\begin{array}{l}\text { No, level } \\
\text { administratively } \\
\text { controlled to } \\
80 \% \text { of } \\
\text { capacity }\end{array}$ \\
\hline $241-\mathrm{AX}-152$ & 34 & $\begin{array}{l}\text { Secondary containment, } \\
\text { drainage from 241-A } \\
\text { complex receiver-AY- } \\
501,241 \text {-AX-155, LINE } \\
\text { V-714 encasement, } 110 \\
\text { seal loop, K1-5-1 } \\
\text { deentrainers, 702-A seal } \\
\text { pot }\end{array}$ & $\begin{array}{l}\text { Cathodic protection } \\
\text { not needed, } \\
\text { stainless steel lined } \\
\text { vault }\end{array}$ & $\begin{array}{l}\text { Assumed yes, } \\
\text { concrete } \\
\text { foundation }\end{array}$ & $\begin{array}{l}\text { Yes, relies on } \\
\text { manual tape } \\
\text { level detection }\end{array}$ & $\begin{array}{l}\text { Yes, level } \\
\text { administratively } \\
\text { controlled--checked } \\
\text { every shift, } \\
\text { administratively } \\
\text { controlled to } 80 \% \\
\text { capacity (OSD-15) }\end{array}$ & No & N/A & N/A & Yes, sump & $\begin{array}{l}\text { No, level } \\
\text { administratively } \\
\text { controlled to } \\
80 \% \text { of } \\
\text { capacity }\end{array}$ \\
\hline $241-\mathrm{AZ}-151$ & 24 & $\begin{array}{l}\text { Primary Containment } \\
\text { receives } \mathrm{AY} / \mathrm{AZ} \\
\text { ventilation condensate, } \\
\text { drainage from } \mathrm{AZ} \text { seal } \\
\text { loops and leak detection } \\
\text { pits, } 801-\mathrm{AZ} \text { inst. } \\
\text { building floor drain, } \\
\text { sluicing box floor drain }\end{array}$ & $\begin{array}{l}\text { Cathodic protection } \\
\text { not needed with } \\
\text { current } \\
\text { configuration }\end{array}$ & $\begin{array}{l}\text { Assumed Yes, } \\
\text { concrete } \\
\text { foundation }\end{array}$ & $\begin{array}{l}\text { Yes, relies on } \\
\text { FIC liquid } \\
\text { level }\end{array}$ & $\begin{array}{l}\text { Yes, } \\
\text { administratively } \\
\text { controlled to } 80 \% \\
\text { capacity (OSD-15) }\end{array}$ & No & $\begin{array}{l}\text { No, concrete } \\
\text { vault with } \\
\text { carbon steel } \\
\text { liner }\end{array}$ & $\begin{array}{l}\text { No secondary } \\
\text { containment }\end{array}$ & $\begin{array}{l}\text { Vault is } \\
\text { sloped, but is } \\
\text { not considered } \\
\text { secondary } \\
\text { containment }\end{array}$ & $\begin{array}{l}\text { No, sump } \\
\text { normally dry but } \\
\text { liquid in sump } \\
\text { would take } \\
\text { longer than } 24 \\
\text { hours to pump }\end{array}$ \\
\hline $241-\mathrm{AZ}-154$ & 24 & $\begin{array}{l}\text { Secondary Containment } \\
\text { or Support. } \\
\text { Receives steam } \\
\text { condensate return from } \\
\text { AZ } 101 \& 102 \text { (lines } \\
\text { capped) }\end{array}$ & $\begin{array}{l}\text { Cathodic protection } \\
\text { not needed, } \\
\text { concrete vault with } \\
10 \text { ga carbon steel } \\
\text { liner }\end{array}$ & $\begin{array}{l}\text { Assumed yes, } \\
\text { concrete } \\
\text { foundation }\end{array}$ & $\begin{array}{l}\text { Yes, relies on } \\
\text { zip cord level } \\
\text { measurement } \\
(E V-040)\end{array}$ & $\begin{array}{l}\text { Yes, overflows to } \\
\text { tank AZ-102, } \\
\text { administratively } \\
\text { controlled to } 80 \% \\
\text { capacity (OSD-15) }\end{array}$ & No & $\mathrm{N} / \mathrm{A}$ & Yes & $\begin{array}{l}\text { Yes, sump in } \\
\text { tank floor }\end{array}$ & $\begin{array}{l}\text { No, level } \\
\text { administratively } \\
\text { controlled to } \\
80 \% \text { of } \\
\text { capacity }\end{array}$ \\
\hline
\end{tabular}




\begin{tabular}{|c|c|c|c|c|c|c|c|c|c|c|c|}
\hline \multirow{2}{*}{ Tank } & \multirow{2}{*}{$\begin{array}{c}\text { Age } \\
\text { (years) }\end{array}$} & \multirow{2}{*}{$\begin{array}{c}\text { Containment } \\
\text { Classification/Waste } \\
\text { Sources }\end{array}$} & \multicolumn{5}{|c|}{ Primary and Secondary Containment } & \multirow{2}{*}{$\begin{array}{c}\text { Primary } \\
\text { Containment } \\
\text { Provided with } \\
\text { Proper } \\
\text { Secondary } \\
\text { Containment? }\end{array}$} & \multicolumn{3}{|c|}{ Secondary Containment } \\
\hline & & & $\begin{array}{l}\text { Corrosion } \\
\text { Protection? }\end{array}$ & $\begin{array}{l}\text { Foundation } \\
\text { Adequate? }\end{array}$ & $\begin{array}{l}\text { Leaks } \\
\text { Detected } \\
\text { within } 24 \\
\text { hours? }\end{array}$ & $\begin{array}{l}\text { Overflow } \\
\text { Protection }\end{array}$ & $\begin{array}{l}\text { Integrity } \\
\text { Assessment } \\
\text { Performed? }\end{array}$ & & $\begin{array}{c}\text { Lining } \\
\text { Compatible } \\
\text { with Waste? }\end{array}$ & $\begin{array}{c}\text { Sloped/ } \\
\text { Designed to } \\
\text { be pumped? }\end{array}$ & $\begin{array}{c}\text { Leaked Waste } \\
\text { Removed } \\
\text { within } 24 \\
\text { hours? }\end{array}$ \\
\hline $241-A-350$ & 18 & $\begin{array}{l}\text { Primary Containment, } \\
\text { receives drainage from } \\
241 \text {-A Tank Farm } \\
\text { through A-A and A-B } \\
\text { valve pits and } 241-A \\
\text { cleanout boxes. Tank } \\
\text { used to route } 207-\mathrm{A} \\
\text { retention basin to AW } \\
\text { farm }\end{array}$ & $\begin{array}{l}\text { No, secondary tank } \\
\text { is direct buried with } \\
\text { no cathodic } \\
\text { protection }\end{array}$ & $\begin{array}{l}\text { Assumed yes, } \\
\text { concrete } \\
\text { foundation }\end{array}$ & $\begin{array}{l}\text { Yes, relies on } \\
\text { weight factor } \\
\text { level detector }\end{array}$ & $\begin{array}{l}\text { Yes, high level } \\
\text { alarm, } \\
\text { administratively } \\
\text { controlled to } 80 \% \\
\text { capacity (OSD-15) }\end{array}$ & No & $\begin{array}{l}\text { No, cannot } \\
\text { verify that } \\
\text { concrete floor } \\
\text { of caisson is } \\
\text { sealed to steel } \\
\text { walls (H-2- } \\
70538 \text { ) }\end{array}$ & $\begin{array}{l}\text { Uncertain, } \\
\text { concrete floor } \\
\text { may not be } \\
\text { adequately } \\
\text { coated }\end{array}$ & Yes, has sump & $\begin{array}{l}\text { No, sump } \\
\text { normally dry but } \\
\text { liquid in sump } \\
\text { would take } \\
\text { longer than } 24 \\
\text { hours to pump }\end{array}$ \\
\hline 204-AR TK-1 & 15 & $\begin{array}{l}\text { Primary Containment, } \\
\text { floor drains from } \\
\text { truck/railcar unloading. }\end{array}$ & $\begin{array}{l}\text { Yes, cathodic } \\
\text { protection not } \\
\text { needed }\end{array}$ & $\begin{array}{l}\text { Assumed yes, } \\
\text { concrete } \\
\text { foundation }\end{array}$ & $\begin{array}{l}\text { Yes, } \\
\text { conductivity } \\
\text { leak detector }\end{array}$ & $\begin{array}{l}\text { Yes, high level } \\
\text { alarm, overflows to } \\
\text { sump }\end{array}$ & No & N/A & Yes & Yes & $\begin{array}{l}\text { No, sump } \\
\text { normally dry but } \\
\text { liquid in sump } \\
\text { would take } \\
\text { longer than } 24 \\
\text { hours to pump }\end{array}$ \\
\hline $241-A-417$ & 37 & $\begin{array}{l}\text { Primary Containment, } \\
\text { receives drainage from } \\
\text { AX-501 valve pit, } 702- \\
\text { A ventilation system } \\
\text { condensate }\end{array}$ & $\begin{array}{l}\text { Cathodic protection } \\
\text { not required with } \\
\text { this configuration }\end{array}$ & $\begin{array}{l}\text { Assumed yes, } \\
\text { concrete } \\
\text { foundation }\end{array}$ & $\begin{array}{l}\text { Yes, relies on } \\
\text { manual zip } \\
\text { cord level } \\
\text { measurement }\end{array}$ & $\begin{array}{l}\text { Yes, overflows to } \\
\text { tank 101-AN }\end{array}$ & No & $\begin{array}{l}\text { No, concrete } \\
\text { vault with } \\
\text { carbon steel } \\
\text { liner }\end{array}$ & N/A & N/A & $\begin{array}{l}\text { N/A - no } \\
\text { secondary exists, } \\
\text { however, waste } \\
\text { is not removed } \\
\text { from the single } \\
\text { containment } \\
\text { within } 24 \text { hours }\end{array}$ \\
\hline $244-A$ & 21 & $\begin{array}{l}\text { Primary Containment, } \\
\text { Receives new cross-site } \\
\text { transfer system flush } \\
\text { water; } 241 \text {-B, BY, BX } \\
\text { stabilization; B- Plant } \\
\text { cleanout }\end{array}$ & $\begin{array}{l}\text { Cathodic protection } \\
\text { Not required with } \\
\text { this configuration }\end{array}$ & Assumed Yes & $\begin{array}{l}\text { Yes, level } \\
\text { indicator in } \\
\text { sump }\end{array}$ & $\begin{array}{l}\text { Yes, high level } \\
\text { alarm, } \\
\text { administratively } \\
\text { controlied to } 80 \% \\
\text { capacity (OSD-15) }\end{array}$ & No & Yes & Yes & Yes, sump & $\begin{array}{l}\text { No, sump } \\
\text { normally dry but } \\
\text { liquid in sump } \\
\text { would take } \\
\text { longer than } 24 \\
\text { lours to pump } \\
\end{array}$ \\
\hline $\begin{array}{l}\text { 244-BX } \\
\text { DCRT }\end{array}$ & 15 & $\begin{array}{l}\text { Primary Containment, } \\
\text { receives waste from } \\
\text { saltwell pumping of B, } \\
B Y \text {, and BX farms }\end{array}$ & $\begin{array}{l}\text { Cathodic protection } \\
\text { Not required with } \\
\text { this configuration }\end{array}$ & Assumed Yes & $\begin{array}{l}\text { Yes, } \\
\text { conductivity } \\
\text { leak detector in } \\
\text { sump }\end{array}$ & $\begin{array}{l}\text { Yes, } \\
\text { administratively } \\
\text { controlled to } 80 \% \\
\text { capacity (OSD-15) }\end{array}$ & No & Yes & Yes & Yes, sump & $\begin{array}{l}\text { No, sump } \\
\text { normally dry but } \\
\text { liquid in sump } \\
\text { would take } \\
\text { longer than } 24 \\
\text { hours to pump }\end{array}$ \\
\hline
\end{tabular}


HNF-SD-TWR-ES-005, Rev. 0

\begin{tabular}{|c|c|c|c|c|c|c|c|c|c|c|c|}
\hline \multirow{2}{*}{ Tank } & \multirow{2}{*}{$\begin{array}{l}\text { Age } \\
\text { (years) }\end{array}$} & \multirow{2}{*}{$\begin{array}{l}\text { Containment } \\
\text { Classification/Waste } \\
\text { Sources }\end{array}$} & \multicolumn{5}{|c|}{ Primary and Secondary Containment } & \multirow{2}{*}{\begin{tabular}{|c|} 
Primary \\
Containment \\
Provided with \\
Proper \\
Secondary \\
Containment?
\end{tabular}} & \multicolumn{3}{|c|}{ Secondary Containment } \\
\hline & & & $\begin{array}{l}\text { Corrosion } \\
\text { Protection? }\end{array}$ & $\begin{array}{l}\text { Foundation } \\
\text { Adequate? }\end{array}$ & $\begin{array}{c}\text { Leaks } \\
\text { Detected } \\
\text { within } 24 \\
\text { hours? }\end{array}$ & $\begin{array}{r}\text { Overflow } \\
\text { Protection }\end{array}$ & $\begin{array}{c}\text { Integrity } \\
\text { Assessment } \\
\text { Performed? }\end{array}$ & & $\begin{array}{c}\text { Lining } \\
\text { Compatible } \\
\text { with Waste? }\end{array}$ & $\begin{array}{c}\text { Sloped/ } \\
\text { Designed to } \\
\text { be pumped? }\end{array}$ & $\begin{array}{c}\text { Leaked Waste } \\
\text { Removed } \\
\text { within } 24 \\
\text { hours? }\end{array}$ \\
\hline 244-CR-003 & 44 & $\begin{array}{l}\text { Primary Containment, } \\
\text { May receive waste from } \\
\text { C-Farm saltwell } \\
\text { pumping }\end{array}$ & $\begin{array}{l}\text { Cathodic protection } \\
\text { not needed }\end{array}$ & $\begin{array}{l}\text { Assumed Yes, } \\
\text { concrete } \\
\text { foundation }\end{array}$ & $\begin{array}{l}\text { Yes, } \\
\text { conductivity } \\
\text { leak detector in } \\
\text { sump }\end{array}$ & Yes & No & Yes & Yes & $\begin{array}{l}\text { Yes, floor has } \\
\text { sump }\end{array}$ & $\begin{array}{l}\text { No, sump } \\
\text { normally dry but } \\
\text { liquid in sump } \\
\text { would take } \\
\text { longer than } 24 \\
\text { hours to pump }\end{array}$ \\
\hline
\end{tabular}


HNF-SD-TWR-ES-005, Rev. 0

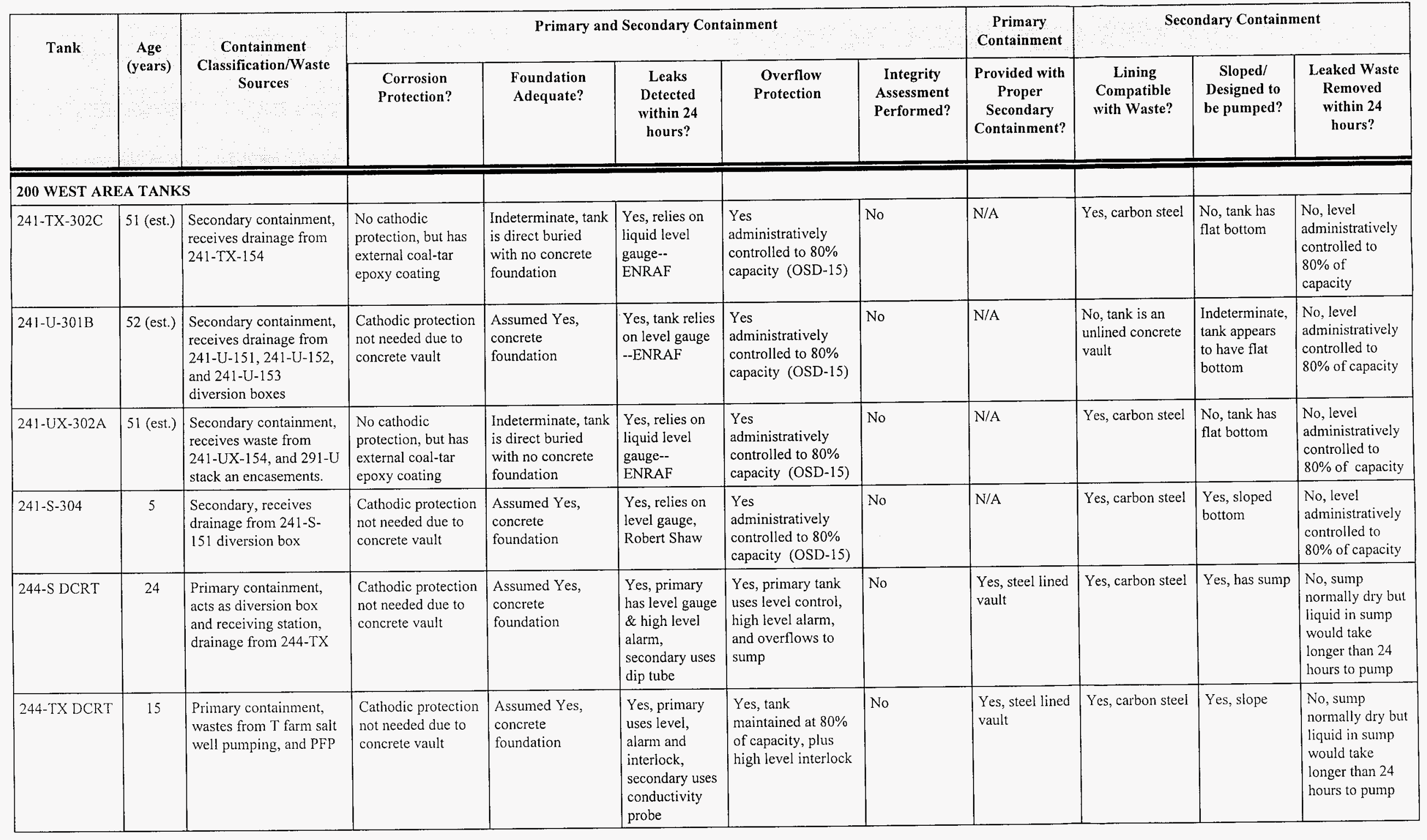


HNF-SD-TWR-ES-005, Rev. 0

\begin{tabular}{|c|c|c|c|c|c|c|c|c|c|c|c|}
\hline \multirow{2}{*}{ Tank } & \multirow{2}{*}{$\begin{array}{c}\text { Age } \\
\text { (years) }\end{array}$} & \multirow{2}{*}{$\begin{array}{c}\text { Containment } \\
\text { Classification/Waste } \\
\text { Sources }\end{array}$} & \multicolumn{5}{|c|}{ Primary and Secondary Containment } & \multirow{2}{*}{$\begin{array}{c}\text { Primary } \\
\text { Containment } \\
\text { Provided with } \\
\text { Proper } \\
\text { Secondary } \\
\text { Containment? }\end{array}$} & \multicolumn{3}{|c|}{ Secondary Containment } \\
\hline & & & $\begin{array}{l}\text { Corrosion } \\
\text { Protection? }\end{array}$ & $\begin{array}{l}\text { Foundation } \\
\text { Adequate? }\end{array}$ & $\begin{array}{c}\text { Leaks } \\
\text { Detected } \\
\text { within } 24 \\
\text { hours? }\end{array}$ & $\begin{array}{l}\text { Overflow } \\
\text { Protection }\end{array}$ & $\begin{array}{c}\text { Integrity } \\
\text { Assessment } \\
\text { Performed? }\end{array}$ & & $\begin{array}{c}\text { Lining } \\
\text { Compatible } \\
\text { with Waste? }\end{array}$ & $\begin{array}{c}\text { Sloped/ } \\
\text { Designed to } \\
\text { be pumped? }\end{array}$ & $\begin{array}{c}\text { Leaked Waste } \\
\text { Removed } \\
\text { within } 24 \\
\text { hours? }\end{array}$ \\
\hline $\begin{array}{l}241-E W-151 \\
\text { Vent Station }\end{array}$ & 41 & $\begin{array}{l}\text { Primary containment, } \\
\text { supports cross-site } \\
\text { transfer pressure tests }\end{array}$ & $\begin{array}{l}\text { Cathodic protection } \\
\text { not needed due to } \\
\text { concrete vault }\end{array}$ & $\begin{array}{l}\text { Assumed Yes, } \\
\text { concrete } \\
\text { foundation }\end{array}$ & $\begin{array}{l}\text { Yes, primary } \\
\text { level } \\
\text { monitored, } \\
\text { secondary } \\
\text { contains } \\
\text { conductivity } \\
\text { probe }\end{array}$ & $\begin{array}{l}\text { Yes, level } \\
\text { monitored, and high } \\
\text { level alarm }\end{array}$ & No & N/A & $\begin{array}{l}\text { Yes, stainless } \\
\text { steel }\end{array}$ & Yes & $\begin{array}{l}\text { No, sump } \\
\text { normally dry but } \\
\text { liquid in sump } \\
\text { would take } \\
\text { longer than } 24 \\
\text { hours to pump }\end{array}$ \\
\hline
\end{tabular}




\section{Appendix B \\ Catch Tank Summary}




\section{TANK FARMS CATCH TANK \\ DEFICIENCY IDENTIFICATION, ALTERNATIVE IDENTIFICATION, AND RECOMMENDATIONS \\ WAC-173-303-640}

\begin{tabular}{|c|c|c|c|c|}
\hline TANK & DEFICIENCIES & $\begin{array}{l}\text { FUTURE } \\
\text { NEEDS }\end{array}$ & ALTERNATIVES & RECOMMENDATION \\
\hline $\begin{array}{l}241-\mathrm{A}-302-\mathrm{A} \\
\text { Secondary } \\
\text { Containment }\end{array}$ & $\begin{array}{l}\text { - No corrosion protection } \\
\text { - Adequate foundation } \\
\text { indeterminate without } \\
\text { further analysis } \\
\text { - No sump or floor slope } \\
\text { - Not operated to remove all } \\
\text { liquid within } 24 \text { hours } \\
\text { - No integrity assessment }\end{array}$ & - None & $\begin{array}{l}\text { Remove the tank from } \\
\text { service (IMUST). } \\
\text { - Continue operation with } \\
\text { the tank as is. }\end{array}$ & $\begin{array}{l}\text { Isolate and put on } \\
\text { IMUST list }\end{array}$ \\
\hline $\begin{array}{l}241-\text { ER-311 } \\
\text { Secondary } \\
\text { Containment }\end{array}$ & $\begin{array}{l}\text { - No corrosion protection } \\
\text { - Adequate foundation } \\
\text { indeterminate without } \\
\text { further analysis } \\
\text { - No sump or floor slope } \\
\text { - Not operated to remove all } \\
\text { liquid within } 24 \text { hours } \\
\text { - No integrity assessment }\end{array}$ & $\begin{array}{l}\text { Short term, supports } \\
\text { current cross-site } \\
\text { transfers (W-058 } \\
\text { completes construction } \\
\text { in }(2 / 98) \\
\text { Short term, supports B- } \\
\text { Plant clean out } \\
\text { (completed in } 98 \text { ) }\end{array}$ & $\begin{array}{l}\text { Conduct an integrity } \\
\text { assessment. } \\
\text { - Remove the tank from } \\
\text { service (IMUST) when } \\
\text { there is no further need. } \\
\text { - Perform a partial upgrade } \\
\text { of the tank. } \\
\text { - Continue operation with } \\
\text { the tank as is. }\end{array}$ & $\begin{array}{l}\text { Continue using existing } \\
\text { tank for } 2 \text { years } \\
\text { - Put on IMUST list as } \\
\text { soon as W-058 comes } \\
\text { on line and B-Plant is } \\
\text { finished. }\end{array}$ \\
\hline $\begin{array}{l}241-A X-152 \\
\text { Secondary } \\
\text { Containment }\end{array}$ & $\begin{array}{l}\text { - Not operated to remove all } \\
\text { liquid within } 24 \text { hours } \\
\text { - No integrity assessment }\end{array}$ & $\begin{array}{l}\text { Short term, After startup } \\
\text { of W-030 only needed } \\
\text { for encasement drains, } \\
\text { lines are non-compliant, } \\
\text { alternate routes available }\end{array}$ & $\begin{array}{l}\text { - Conduct an integrity } \\
\text { assessment. } \\
\text { - Remove the tank from } \\
\text { service (IMUST) when } \\
\text { there is no further need. } \\
\text { - Perform a partial upgrade } \\
\text { of the tank. } \\
\text { - Continue operation with } \\
\text { the tank as is. }\end{array}$ & $\begin{array}{l}\text { Continue operation } \\
\text { through W-030 startup } \\
\text { then put on IMUST list }\end{array}$ \\
\hline
\end{tabular}




\begin{tabular}{|c|c|c|c|c|}
\hline TANK & DEFICIENCIES & $\begin{array}{c}\text { FUTURE } \\
\text { NEEDS }\end{array}$ & ALTERNATIVES & RECOMMENDATION \\
\hline $\begin{array}{l}241-\mathrm{AZ}-151 \\
\text { Primary } \\
\text { Containment }\end{array}$ & $\begin{array}{l}\text { - Inadequate secondary } \\
\text { containment--CS lined } \\
\text { Concrete vault } \\
\text { - No integrity assessment }\end{array}$ & $\begin{array}{l}\text { - Long term, Collects } \\
\text { condensate from W-030 } \\
\text { - Long term, AZ farm seal } \\
\text { loops and leak detection } \\
\text { pit }\end{array}$ & $\begin{array}{l}\text { - Conduct an integrity } \\
\text { assessment. } \\
\text { - Determine another means } \\
\text { of meeting the tank } \\
\text { function. } \\
\text { - Perform a partial upgrade } \\
\text { of the tank. } \\
\text { - Perform a total upgrade of } \\
\text { the tank. } \\
\text { - Continue operation with } \\
\text { the tank as is. }\end{array}$ & $\begin{array}{l}\text { Upgrade by replacing } \\
\text { catch tank or rerouting } \\
\text { waste to compliant tank }\end{array}$ \\
\hline $\begin{array}{l}241-\mathrm{A}-350 \\
\text { Primary } \\
\text { Containment }\end{array}$ & $\begin{array}{l}\text { Caisson and concrete } \\
\text { floor may not provide } \\
\text { adequate secondary } \\
\text { containment } \\
\text { - Not operated to remove all } \\
\text { liquid within } 24 \text { hours } \\
\text { No integrity assessment }\end{array}$ & $\begin{array}{l}\text { Long-term, provides } \\
\text { secondary containment } \\
\text { for AA \& AB valve pits } \\
\text { 207-A retention basin } \\
\text { routing }\end{array}$ & $\begin{array}{l}\text { - Conduct an integrity } \\
\text { assessment. } \\
\text { - Determine another means } \\
\text { of meeting the tank } \\
\text { function. } \\
\text { - Perform a partial upgrade } \\
\text { of the tank. } \\
\text { - Perform a total upgrade of } \\
\text { the tank. } \\
\text { - Continue operation with } \\
\text { the tank as is. }\end{array}$ & $\begin{array}{l}\text { Perform integrity } \\
\text { assessment. } \\
\text { - Continue current } \\
\text { operations. } \\
\text { - Only upgrade if the } \\
\text { results of the integrity } \\
\text { assessment indicate } \\
\text { significant deficiencies. }\end{array}$ \\
\hline
\end{tabular}




\begin{tabular}{|c|c|c|c|c|}
\hline TANK & DEFICIENCIES & $\begin{array}{l}\text { FUTURE } \\
\text { NEEDS }\end{array}$ & ALTERNATIVES & RECOMMENDATION \\
\hline $\begin{array}{l}\text { 204-AR-TK-1 } \\
\text { Secondary } \\
\text { Containment }\end{array}$ & $\begin{array}{l}\text { - Not operated to remove all } \\
\text { liquid within } 24 \text { hours } \\
\text { - No integrity assessment }\end{array}$ & $\begin{array}{l}\text { Long term need in } \\
\text { support of truck and } \\
\text { railcar waste transports }\end{array}$ & $\begin{array}{l}\text { Conduct an integrity } \\
\text { assessment. } \\
\text { Determine another means } \\
\text { of meeting the tank } \\
\text { function. } \\
\text { - Perform a partial upgrade } \\
\text { of the tank. } \\
\text { - Perform a total upgrade of } \\
\text { the tank. } \\
\text { Continue operation with } \\
\text { the tank as is. }\end{array}$ & $\begin{array}{l}\text { Perform integrity } \\
\text { assessment } \\
\text { - Negotiate pumping } \\
\text { arrangement with } \\
\text { Ecology }\end{array}$ \\
\hline $\begin{array}{l}241-A-417 \\
\text { Primary } \\
\text { Containment }\end{array}$ & $\begin{array}{l}\text { - Inadequate secondary } \\
\text { containment--CS lined } \\
\text { Concrete vault } \\
\text { - Not operated to remove all } \\
\text { liquid within } 24 \text { hours } \\
\text { - No integrity assessment }\end{array}$ & $\begin{array}{l}\text { None after completion of } \\
\text { Project W-030 (7/97) }\end{array}$ & $\begin{array}{l}\text { - Conduct an integrity } \\
\text { assessment. } \\
\text { - Remove the tank from } \\
\text { service (IMUST) when } \\
\text { there is no further need. } \\
\text { - Perform a partial upgrade } \\
\text { of the tank. } \\
\text { - Continue operation with } \\
\text { the tank as is. }\end{array}$ & $\begin{array}{l}\text { Continue current } \\
\text { operation } \\
\text { - Place in IMUST list } \\
\text { after W-030 ventilation } \\
\text { system startup (7/1997) }\end{array}$ \\
\hline $\begin{array}{l}\text { 244-A DCRT } \\
\text { Primary } \\
\text { Containment }\end{array}$ & $\begin{array}{l}\text { - Ventilation system out of } \\
\text { compliance with WAC- } \\
\text { 246-247 (WHC-SD-WM- } \\
\text { ES- 002) } \\
\text { - No integrity assessment } \\
\text { - Not operated to remove all } \\
\text { liquid from secondary } \\
\text { containment sump within } \\
24 \text { hours }\end{array}$ & $\begin{array}{l}\text { Long-term need to } \\
\text { support cross-site } \\
\text { transfers; however, } \\
\text { Project W-314 plans to } \\
\text { bypass } 244-\text { A (FY 2000 } \\
\text { or later) } \\
\text { - Short term need to } \\
\text { support B-Plant clean } \\
\text { out (FY 98) } \\
\text { Short term, supports B- } \\
\text { Farm saltwell pumping, } \\
\text { tank C-103 pumping } \\
(9 / 2000 \text { ) }\end{array}$ & $\begin{array}{l}\text { - Conduct an integrity } \\
\text { assessment. } \\
\text { - Determine another means } \\
\text { of meeting the tank } \\
\text { function. } \\
\text { - Perform a partial upgrade } \\
\text { of the tank. } \\
\text { - Perform a total upgrade of } \\
\text { the tank. } \\
\text { - Continue operation with } \\
\text { the tank as is. }\end{array}$ & $\begin{array}{l}\text { Conduct an integrity } \\
\text { assessment } \\
\text { - Continue current } \\
\text { operation } \\
\text { - Place in IMUST list } \\
\text { after W-314 bypasses } \\
\text { (after 2002) }\end{array}$ \\
\hline
\end{tabular}




\begin{tabular}{|c|c|c|c|c|}
\hline TANK & DEFICIENCIES & $\begin{array}{c}\text { FUTURE } \\
\text { NEEDS }\end{array}$ & ALTERNATIVES & RECOMMENDATION \\
\hline $\begin{array}{l}\text { 244-BX } \\
\text { DCRT } \\
\text { Primary } \\
\text { Containment }\end{array}$ & $\begin{array}{l}\text { - Ventilation system out of } \\
\text { compliance with WAC- } \\
\text { 246-247 (WHC-SD-WM- } \\
\text { ES- 002) } \\
\text { - No integrity assessment }\end{array}$ & $\begin{array}{l}\text { - Short term, supports B, } \\
\text { BY, \& BX Farm } \\
\text { stabilization }(9 / 2000)\end{array}$ & $\begin{array}{l}\text { - Conduct an integrity } \\
\text { assessment. } \\
\text { - Remove the tank from } \\
\text { service (IMUST) when } \\
\text { there is no further need. } \\
\text { - Perform a partial upgrade } \\
\text { of the tank. } \\
\text { - Continue operation with } \\
\text { the tank as is. }\end{array}$ & $\begin{array}{l}\text { - Conduct an integrity } \\
\text { assessment } \\
\text { - Continue current } \\
\text { operation }\end{array}$ \\
\hline $\begin{array}{l}244-\mathrm{CR} \text { tank } \\
003 \\
\text { Primary } \\
\text { Containment }\end{array}$ & $\begin{array}{l}\text { Ventilation system out of } \\
\text { compliance with WAC- } \\
246-247 \\
\text { - No integrity assessment }\end{array}$ & $\begin{array}{l}\text { Short term, } \\
\text { supports stabilization of } \\
\text { tank C-103 }(9 / 2000)\end{array}$ & $\begin{array}{l}\text { Conduct an integrity } \\
\text { assessment. } \\
\text { - Remove the tank from } \\
\text { service (IMUST) when } \\
\text { there is no further need. } \\
\text { - Perform a partial upgrade } \\
\text { of the tank. } \\
\text { - Continue operation with } \\
\text { the tank as is. }\end{array}$ & $\begin{array}{l}\text { - Conduct an integrity } \\
\text { assessment } \\
\text { - Place on IMUST list } \\
\text { after C-103 stabilization }\end{array}$ \\
\hline
\end{tabular}




\begin{tabular}{|c|c|c|c|c|}
\hline TANK & DEFICIENCIES & $\begin{array}{l}\text { FUTURE } \\
\text { NEEDS }\end{array}$ & AITERNATIVES & RECOMMENDATION \\
\hline \multicolumn{5}{|c|}{200 WEST AREA TANKS } \\
\hline $\begin{array}{l}241-\mathrm{TX}-302-\mathrm{C} \\
\text { Secondary } \\
\text { Containment }\end{array}$ & $\begin{array}{l}\text { - No integrity assessment } \\
\text { - No corrosion protection } \\
\text { - Adequate foundation } \\
\text { indeterminate without } \\
\text { further analysis } \\
\text { - No sump or floor slope } \\
\text { - Not operated to remove all } \\
\text { liquid within } 24 \text { hours }\end{array}$ & $\begin{array}{l}\text { None, T- Plant transfers } \\
\text { now being done by } \\
\text { railcar }\end{array}$ & $\begin{array}{l}\text { Remove the tank from } \\
\text { service (IMUST). } \\
\text { - Continue operation with } \\
\text { the tank as is. }\end{array}$ & $\begin{array}{l}\text { Isolate and place on } \\
\text { IMUST list }\end{array}$ \\
\hline $\begin{array}{l}241-\mathrm{U}-301 \mathrm{~B} \\
\text { Secondary } \\
\text { Containment }\end{array}$ & $\begin{array}{l}\text { - No integrity assessment } \\
\text { - Tank construction is } \\
\text { unlined concrete } \\
\text { - No sump or floor slope } \\
\text { - Not operated to remove all } \\
\text { liquid within } 24 \text { hours }\end{array}$ & $\begin{array}{l}\text { Long term need to } \\
\text { support } 244-\mathrm{TX}(2006) \\
\text { transfers routed through } \\
241-\mathrm{U}-15 \mathrm{I} \text { and } 241-\mathrm{U}- \\
152 \text {; includes T farm salt } \\
\text { well pumping }(9 / 2000) \\
\text { and PFP transfers }(2006)\end{array}$ & $\begin{array}{l}\text { - Conduct an integrity } \\
\text { assessment. } \\
\text { - Determine another means } \\
\text { of meeting the tank } \\
\text { function. } \\
\text { - Perform a total upgrade of } \\
\text { the tank. } \\
\text { - Continue operation with } \\
\text { the tank as is. }\end{array}$ & $\begin{array}{l}\text { Upgrade by replacing } \\
\text { catch tank or rerouting } \\
\text { waste to compliant tank }\end{array}$ \\
\hline $\begin{array}{l}241-\mathrm{UX}-302 \mathrm{~A} \\
\text { Secondary } \\
\text { Containment }\end{array}$ & $\begin{array}{l}\text { - No integrity assessment } \\
\text { - Corrosion protection may } \\
\text { not be adequate } \\
\text { - Adequate foundation } \\
\text { indeterminate without } \\
\text { further analysis } \\
\text { - No sump or floor slope } \\
\text { - Not operated to remove all } \\
\text { liquid within } 24 \text { hours }\end{array}$ & $\begin{array}{l}\text { Short term need to } \\
\text { support cross-site } \\
\text { transfers until W-058 } \\
\text { completion (2/98) } \\
\text { - Long term supports 291- } \\
\text { U stack and encasement } \\
\text { drains }\end{array}$ & $\begin{array}{l}\text { - Conduct an integrity } \\
\text { assessment. } \\
\text { - Determine another means } \\
\text { of meeting the tank } \\
\text { function. } \\
\text { - Perform a total upgrade of } \\
\text { the tank. } \\
\text { - Continue operation with } \\
\text { the tank as is. }\end{array}$ & $\begin{array}{l}\text { Continue operation as- } \\
\text { is } \\
\text { - Isolate and place on } \\
\text { IMUST list when no } \\
\text { longer needed }\end{array}$ \\
\hline
\end{tabular}




\begin{tabular}{|c|c|c|c|c|}
\hline TANK & DEFICIENCIES & $\begin{array}{c}\text { FUTURE } \\
\text { NEEDS }\end{array}$ & ALTERNATIVES & RECOMMENDATION \\
\hline $\begin{array}{l}\text { 241-S-304 } \\
\text { Secondary } \\
\text { Containment }\end{array}$ & $\begin{array}{l}\text { No integrity assessment } \\
\text { Not operated to remove all } \\
\text { liquid within } 24 \text { hours }\end{array}$ & $\begin{array}{l}\text { Long term drainage from } \\
241-\mathrm{S}-151 \text { supports } 244- \\
\text { TX transfers (2006) }\end{array}$ & $\begin{array}{l}\text { - Conduct an integrity } \\
\text { assessment. } \\
\text { - Determine another means } \\
\text { of meeting the tank } \\
\text { function. } \\
\text { - Perform a partial upgrade } \\
\text { of the tank. } \\
\text { - Perform a total upgrade of } \\
\text { the tank. } \\
\text { - Continue operation with } \\
\text { the tank as is. }\end{array}$ & $\begin{array}{l}\text { Conduct an integrity } \\
\text { assessment } \\
\text { Continue current } \\
\text { operations, but inform } \\
\text { Ecology sump can not } \\
\text { be pumped within } 24 \\
\text { hours if liquid should } \\
\text { get in it }\end{array}$ \\
\hline $\begin{array}{l}244-S \\
\text { DCRT } \\
\text { Primary } \\
\text { Containment }\end{array}$ & $\begin{array}{l}\text { No integrity assessment } \\
\text { Secondary containment } \\
\text { sump not operated to } \\
\text { remove all liquid within } 24 \\
\text { hours }\end{array}$ & $\begin{array}{l}\text { - Short term, supports S \& } \\
\text { SX farm saltwell } \\
\text { pumping ( } 9 / 2000) \\
\text { - Short term, supports } \\
\text { current cross-site } \\
\text { transfers }(9 / 98) \\
\text { - Long term, receives } \\
\text { waste from } 222-S \text { labs } \\
\text { upon completion of } \\
\text { project } \mathrm{W}-087 \\
\text { - Long term, acts as } \\
\text { diversion box for most } \\
\text { West area waste } \\
\text { transfers }\end{array}$ & $\begin{array}{l}\text { - Conduct an integrity } \\
\text { assessment. } \\
\text { - Determine another means } \\
\text { of meeting the tank } \\
\text { function. } \\
\text { - Perform a partial upgrade } \\
\text { of the tank. } \\
\text { - Perform a total upgrade of } \\
\text { the tank. } \\
\text { - Continue operation with } \\
\text { the tank as is. }\end{array}$ & $\begin{array}{l}\text { - Conduct an integrity } \\
\text { assessment } \\
\text { - Continue current } \\
\text { operation, but inform } \\
\text { Ecology sump can not } \\
\text { be pumped within } 24 \\
\text { hours if liquid should } \\
\text { get in it }\end{array}$ \\
\hline
\end{tabular}




\begin{tabular}{|c|c|c|c|c|}
\hline TANK & DEFICIENCIES & $\begin{array}{c}\text { FUTURE } \\
\text { NEEDS }\end{array}$ & ALTERNATIVES & RECOMMENDATION \\
\hline $\begin{array}{l}\text { 244-TX } \\
\text { DCRT } \\
\text { Primary } \\
\text { Containment }\end{array}$ & $\begin{array}{l}\text { - No integrity assessment } \\
\text { Secondary containment } \\
\text { sump not operated to } \\
\text { remove all liquid within } 24 \\
\text { hours }\end{array}$ & $\begin{array}{l}\text { - Short term, supports T- } \\
\text { Farm salt well pumping } \\
(9 / 2000) \\
\text {, Long term, supports PFP } \\
\text { transfers (2006) }\end{array}$ & $\begin{array}{l}\text { Conduct an integrity } \\
\text { assessment. } \\
\text { Determine another means } \\
\text { of meeting the tank } \\
\text { function. } \\
\text { - Perform a partial upgrade } \\
\text { of the tank. } \\
\text { - Perform a total upgrade of } \\
\text { the tank. } \\
\text { - Continue operation with } \\
\text { the tank as is. }\end{array}$ & $\begin{array}{l}\text { - Conduct an integrity } \\
\text { assessment } \\
\text { - Continue current } \\
\text { operation, but inform } \\
\text { Ecology sump can not } \\
\text { be pumped within } 24 \\
\text { hours if liquid should } \\
\text { get in it }\end{array}$ \\
\hline $\begin{array}{l}\text { 241-EW-151 } \\
\text { Primary } \\
\text { Containment }\end{array}$ & $\begin{array}{l}\text { No integrity assessment } \\
\text { Secondary containment } \\
\text { sump not operated to } \\
\text { remove all liquid within } 24 \\
\text { hours }\end{array}$ & $\begin{array}{l}\text { - Short term, supports } \\
\text { current cross-site } \\
\text { transfers }(2 / 98)\end{array}$ & $\begin{array}{l}\text { - Conduct an integrity } \\
\text { assessment. } \\
\text { - Remove the tank from } \\
\text { service (IMUST) when } \\
\text { there is no further need. } \\
\text { - Perform a partial upgrade } \\
\text { of the tank. } \\
\text { - Continue operation with } \\
\text { the tank as is. }\end{array}$ & $\begin{array}{l}\text { Continue using existing } \\
\text { system until Project W- } \\
058 \text { is complete } \\
\text { - Put on IMUST list as } \\
\text { W- } 058 \text { is finished }\end{array}$ \\
\hline
\end{tabular}


DISTRIBUTION:

Lockheed Mart in Hanford Corporation

D. Alison R1-51

P. C. Miller R1-51

R. K. P'Pool S5-03

D. W. Reberger S5-13

W. E. Ross S5-07

M. J. Sutey T4-08

J. M. Thurman R1-51

Numatec Hanford Corporation

J. M. Light R3-25

R. W. Mattichak R3-25 